\title{
Penerapan Metode Naïve Bayes dalam Analisis Persepsi Masyarakat mengenai Rencana Pengesahan RUU Omnibus Law di Bidang Investasi dan Ketenagakerjaan Tahun 2020 di Indonesia
}

Najia Helmiah

PoliteknikStatistika STIS,njiahlm@gmail.com

Rani Nooraeni

PoliteknikStatistika STIS, raninoor@stis.ac.id

Aldi Rochman Nulkarim

Politeknik Statistika STIS, 211709552@stis.ac.id

Nufaisa Munia, Amalia Susanti

Politeknik Statistika STIS, 211709908@stis.ac.id

Amalia Susanti

Politeknik Statistika STIS, 211709538@stis.ac.id

Amran Pratama Putra

Politeknik Statistika STIS, 211709538@stis.ac.id

Febi Taufiqurrahman

Politeknik Statistika STIS, 211709698@stis.ac.id

ABSTRAK, Saat ini, RUU Omnibus Law di Indonesia menjadi kontroversi, khususnya mengenai RUU Cipta Kerja karena dianggap memiliki dampak negative bagi pekerja/buruh. Hal tersebut terlihat dari banyaknya unjuk rasa yang dilakukan dalam rangka menolak RUU tersebut. Penyampaian pendapapat tidak hanya dilakukan melalui unjuk rasa, tetapi juga dapat melalui media social. Salah satunya adalah twitter. Sehingga, penelitian ini bertujuan untuk mengklasifikasikan opini masyarakat mengenai rencana pengesahan RUU Omnibus Law melalui data twitter. Analisis sentiment, asosiasi kata, dan metode Nä̈ve Bayes Classifier diterapakan untuk mengetahui kata-kata yang sering dicuitkan mengenai Omnibus Law dan keterkaitan antar kata, serta mengklasifikasikan opini masyarakat terhadap rencana pengesahan RUU Omnibus Law baik secara emosional maupun secara polaritas. Data yang digunakan adalah data cuitan twitter dari tanggal 5 Januari 2020 hingga 30 Agustus 2020 dengan data hasil preprocessing sebanyak 8820 tweets. Hasilnya menunjukan bahwa sebagaian besar kata dalam tweet membahas tentang ketenagakerjaan. Berdasarkan analisis asosiasi kata, kata investasi memiliki keterkaitan yang erat dengan pertumbuhan ekonomi serta kemudahan regulasi, sedangkan kata cipta memiliki keterkaitan erat dengan penciptaan lapangan pekerjaan, dan kata buruh memiiki keterkaitan erat dengan penolakan. Kemudian, berdasarkan analisis sentiment, $54 \%$ cuitan terklasifikasi sebagai sentiment negative dan $46 \%$ cuitan terklasifikasi sebagai sentiment positif. Dengan metode Nä̈ve Bayes, model yang terbentuk dapat mengklasifikasikan $87.1 \%$ cuitan twitter dengan benar atau dengan kata lain tingkat akurasi model sebesar $87.1 \%$.

Kata Kunci: Omnibus Law, Nä̈ve Bayes, Text Mining, Twitter, Buruh

\section{PENDAHULUAN}

Investasi merupakan salah satu upaya dan aspek yang memiliki peran strategis dalam pembangunan ekonomi nasional, sesuai dengan teori pertumbuhan ekonomi oleh Robert Solow dengan pendekatan Neo-Klasik yang menyatakan bahwa pembentukan modal dan pertumbuhan penduduk merupakan faktor yang berpengaruh signifikan terhadap pertumbuhan ekononi suatu negara. Selain meningkatkan pertumbuhan ekonomi, investasi juga dapat meningkatkan kesempatan kerja. Dimana dengan semakin tingginya serapan tenaga kerja akan meningkatkan produktivitas yang pada akhirnya meningkatkan pertumbuhan ekonomi. Hal ini juga yang mendasari peranan investasi sebagai "engine of growth" [8].

Kondisi investasi di Indonesia yang dapat ditunjukkan oleh realisasi investasi cenderung menunjukan peningkatan setiap tahunnya. Namun, rata-rata arus masuk PMA ke Indonesia dalam lima tahun terakhir masih minim yaitu sebesar 1,9\% terhadap Produk Domestik Bruto (PDB), jauh di bawah Kamboja (11,8\% PDB), Vietnam (5,9\% PDB), Malaysia (3,5\% PDB), dan Thailand $(2,6 \%$ PDB) [7]. Selain itu, beberapa paket kebijakan ekonomi yang 
dikeluarkan pemerintah dalam rangka mempermudah investor untuk menanamkan modalnya di Indonesia, dirasa belum berhasil untuk meningkatkan investasi dan pertumbuhan ekonomi. Tercermin dari tingkat pertumbuhan ekonomi Indonesia yang stagnan di 5\% [18]. Menurut Badan Koordinasi Penanaman Modal (BKPM) melambatnya investasi di Indonesia dikarenakan oleh lima kendala, yaitu regulasi yang masih berbelit, akuisisi lahan yang sulit, infrastruktur publik yang belum merata, pajak dan insentif nonfiskal yang belum mendukung investasi, serta tenaga kerja terampil yang belum memadai [7].

Oleh karena itu, untuk menarik minat para investor, pemerintah menyiapkan RUU Omnibus Law. RUU ini pertama kali didengungkan pada pidato pelantikan Presiden Jokowi tahun 2019. Omnibus Law merupakan konsepmenggabungkan beberapa aturan yang substansi pengaturannya berbeda, menjadi satu peraturan dalam satu payung hukum. Dalam omnibus law, terdapat tiga RUU yang siap diundangkan, antara lain: RUU tentang Cipta Kerja, RUU tentang Ketentuan dan Fasilitas Perpajakan untuk Penguatan Perekonomian, dan RUU tentang Pengembangan dan Penguatan Sektor Keuangan. Hal tersebut dilatarbelakangi perlambatan ekonomi global, potensi stagnasi perekonomian Indonesia (middle income trap) dan belum optimalnya daya saing Indonesia. RUU Omnibus Law diharapkan menjadi solusi dalam mengatasi tumpang tindihnya regulasi, sekaligus juga kemudahan berusaha yang dapat mendongkrak peringkat Indonesia. Sehingga, arus masuk investasi bagi kepentingan pembangunan, penciptaan lapangan kerja dan pertumbuhan ekonomi dapat meningkat [6]

Selain memiliki sisi positif, pembentukan RUU Omnibus Law juga dilihat memiliki dampak negatif, khususnya bagi para pekerja. Omnibus Law dikatakan merugikan pekerja karena dianggap memperpanjang jam kerja dan lembur, upah minimum menjadi rendah, adanya potensi terjadi pelanggaran hak berserikat pekerja, adanya pemangkasan kewenangan serikat pekerja, serta hilangnya hak-hak pekerja perempuan untuk cuti haid, hamil dan keguguran
[4]. Hal tersebut menyebabkan adanya penolakan dari kaum buruh terhadap rencana pengesahaan RUU ini. Terlihat dari berbagai unjuk rasa yang dilakukan, dimulai sejak pertengahan bulan Maret 2020 hingga puncaknya di bulan Oktober 2020 setelah pengumuman pengesahan RUU Omnibus Law.

Aspirasi rakyat merupakan salah satu komponen penting sebelum dilakukan pengesahan RUU karena Indonesia merupakan negara demokrasi dimana rakyat memiliki kekuasaan tertinggi dalam pemerintahan. Hal tersebut tertuang dalam pasal 53 UU Republik Indonesia Nomor 10 Tahun 2004 Tentang Pembantukan Peraturan Perundang-Undangan yang menyatakan bahwa: "Masyarakat berhak memberikan masukan secara lisan atau tertulis dalam rangka penyiapan atau pembahasan rancangan undang-undang dan rancangan peraturan daerah". Penyampaian aspirasi tidak hanya terjadi secara langsung melalui unjuk rasa, tetapi juga terjadi melalui media sosial. Hal tersebut karena ruang digital semacam internet dan media sosial dirasa memiliki kemampuan untuk menciptakan deliberasi demokrasi [5].

Twitter merupakan salah satu media sosial dengan pengguna terbanyak. Melalui Twitter, banyak masyarakat yang memperbincangkan berbagai isu hangat yang sedang terjadi, baik di bidang pendidikan, ekonomi, politik, sosial budaya, entertainment, hingga pemerintahan, tidak terkecuali rencana pembentukan RUU Omnibus Law. Hal tersebut dapat ditunjukan dengan banyaknya cuitan masyarakat di media sosial twitter beserta hashtag yang mendukung maupun menolak rencana pengesahan RUU ini, beberapa contoh hashtag yang mendukung seperti \#Indonesiabutuhkerja, \#Ciptakerja kemudian hastag yang menolak seperti \#Gejayanmemanggillagi, \#JegalOmnibusLaw, dll. Maka dari itu, penting untuk mengetahui apa saja kata-kata yang sering dicuitkan mengenai Omnibus Law dan keterkaitan antar kata, serta bagaimana sentiment masyarakat terkait rencana pengesahan RUU Omnibus Law berdasarkan cuitan twitter. 
Penelitian mengenai sentiment masyarakat berdasarkan cuitan twitter telah banyak dilakukan. Seperti penelitian yang dilakukan oleh Bimananda dkk tahun 2019 untuk mengklasifikasikan opini masyarakat terhadap pembangunan infrastruktur di Indonesia. Sentimen polaritas dengan mengklasifikasikan data menjadi sentimen positif dan sentimen negatif. Metode klasifikasi yang digunakan adalah Naïve Bayes Classifier (NBC). Penelitian lainnya dilakukan oleh Fransiska dan Yolanda tahun 2019 untuk mengklasifikasikan opini pengguna twitter terhadap film Parasite. Terdapat dua jenis sentimen yang dilakukan. Pertama, sentimen emotion dengan mengklasifikasikan data menjadi enam, yaitu joy, sadness, anger, disgust, fear, dan surprise. Kedua sentimen polarity dengan mengklasifikasikan data menjadi sentimen positif, sentimen netral, dan sentimen negatif. Metode klasifikasi yang digunakan dalampenelitian ini adalah Naïve Bayes Classifier (NBC). Kebaharuan pada penelitian ini adalah topik Omnibus Law yang berdasarkan studi literatur, belum ada penelitian yang mengkaji hal ini dengan analisis sentiment cuitan twitter.

Berdasarkan latar belakang tersebut, penelitian ini bertujuan untuk mengetahui kata-kata yang sering dicuitkan mengenai Omnibus Law dan keterkaitan antar kata, serta mengklasifikasikan opini masyarakat terkait rencana pengesahan RUU Omnibus Law baik secara emosional maupun secara polaritas sehingga hal tersebut dapat menjadi sumber yang bermanfaat bagi pemerintah dalam mengambil kebijakan.

\section{TINJAUAN PUSTAKA}

\section{Omnibus Law}

Omnibus Law merupakan metode atau konsep yang mengganti dan atau mencabut UU/beberapa ketentuan dalam UU serta diatur ulang dalam satu UU (tematik). Omnibus law merupakan konsep yang ada dan dipraktikkan dalam suatu negara yang menganut common law system. Konsep ini bertujuan untuk memperbaiki berbagai regulasi di negaranya dalam rangka meningkatkan iklim dan daya saing investasi [19].

\section{Twitter}

Microblogging merupakan bentuk komunikasi yang penggunanya dapat menggambarkan status mereka saat ini melalui postingan singkat dalam bentuk pesan instan, ponsel, email, atau web [15]. Twitter merupakan microblogging paling popular yang memungkinkan pengguna untuk mengirim postingan singkat yang disebut dengan tweet. Pengguna twitter menggunakan aplikasi twitter dengan beberapa tujuan, yaitu untuk memposting tentang rutinitas sehari-hari, berkomunikasi, berbagi informasi (URLs), dan melaporkan berita termasuk memberikan komentar serta opini terhadap peristiwa terkini.

\section{Text Mining}

Text mining merupakan proses menggali pola atau informasi yang menarik [14] baik dari data teks semi-terstruktur maupun tidak terstruktur dengan menggunakan alat analisis tertentu [1]. Text mining dapat digunakan untuk mengklasifikasikan dokumen teks berupa opini berdasarkan sentimen.

\section{Association Rules dan Word Embedding}

Analisis asosiasi atau association rules mining merupakan sebuah metode yang digunakan untuk menemukan aturan asosiasi dari suatu kombinasi item. Contohnya pada analisa kemungkinan seorang pelanggan membeli komputer bersamaan dengan software [12]. Natural language processing (NLP) merupakan salah satu cabang ilmu AI yang berfokus pada pengolahan bahasa natural. Salah satu model yang banyak diterapkan pada NLP adalah word embedding. Word embedding merupakan pendekatan yang memanfaatkan urutan kata dalam dokumen teks, secara eksplisit memodelkan asumsi bahwa katakata yang lebih dekat dalam urutan kata lebih bergantung secara statistik [17].

\section{Analisis Sentimen}

Analisis sentimen, juga disebut sebagai opinion mining, merupakan bidang studi yang menganalisis pendapat, sentimen, evaluasi, penilaian, sikap, dan emosi terhadap suatu 
peristiwa, topik, organisasi, maupun perorangan yang dituangkan dalam bentuk teks [9].

\section{Naïve Bayes Classifier}

Naïve Bayes merupakan metode pengklasifikasian statistik yang dapat digunakan untuk memprediksi probabilitas keanggotaan kelas, seperti probabilitas tupel tertentu untuk masuk ke dalam kelas tertentu. Metode ini mengasumsikan semua atribut independen dan dalam praktiknya memberikan akurasi dan kecepatan yang cukup tinggi pada saat digunakan pada data ukuran besar [12]. Naïve Bayes terbukti efektif dalam berbagai pengaplikasian, salah satunya klasifikasi teks [10].

Metode ini menggunakan Teorema Bayes, yaitu sebagai berikut:

$$
P(H \mid X)=\frac{P(X \mid H) \cdot P(H)}{P(X)}
$$

Dimana:

$X \quad$ : Data dengan kelas yang belum diketahui

$H$ : $\quad$ Hipotesis data merupakan suatu kelas spesifik

$P(H \mid X)$ : Probabilitas hipotesis $H$ berdasarkan kondisi X (probabilitas posterior)

$P(H)$ : Probabilitas hipotesis $H$ (probabilitas prior)

$P(X \mid H)$ : Probabilitas $X$ berdasarkan kondisi pada hipotesis $H$

$P(X)$ : Probabilitas $X$

\section{Matrix Confussion}

Kemampuan prediksi algoritma klasifikasi biasanya diukur dengan menggunakan akurasi prediktifnya (atau tingkat kesalahan, yaitu 1 akurasi) terhadap set data pengujian [16]. Akurasi pengklasifikasi pada set data pengujian yang diberikan adalah persentase tupel set pengujian yang diklasifikasikan dengan benar oleh pengklasifikasi. Matrix confusion merupakan salah satu alat untuk mengukur tingkat akurasi dari suatu pengklasifikasian.

\section{METODOLOGI}

\section{Alur Penelitian}

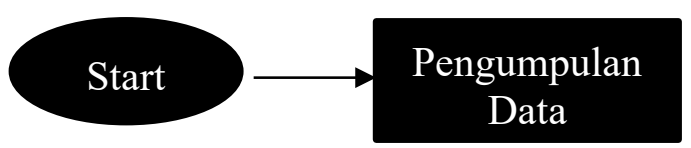

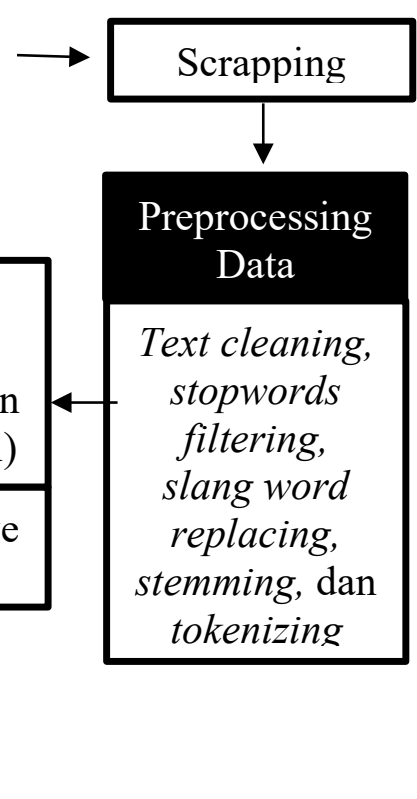

\section{Sumber Data}

Pegambilan data menggunakan python dengan package twint untuk mengambil data tweets dengan keywords "Omnibus Law", "\#OmnibusLaw”,"\#CiptaKerja”,"\#GagalkanOm nibusLaw”, “\#GejayanMemanggilLagi”,“\#Indon esiaButuhKerja", dan "\#Ciptaker". Tweets yang diambil hanya yang menggunakan bahasa Indonesia selama periode waktu 5 Januari 2020 hingga 30 Agustus 2020. Selanjutnya, data tweets yang terambil akan disimpan dalam bentuk file CSV yang berisi atribut username, fullname, user ID, tweet ID, tweet url, time stamp, time stamp epochs, replies, retweets, likes, is retweet, retweeter username, retweeter user ID, retweet ID, text, dan HTML. Data yang diperoleh sebanyak 89247 tweets yang akan dilanjutkan pada proses preprocessing, olah data, dan analisis.

\section{Preprocessing Data}

1. Text cleaning: Pada tahap ini dataset hasil crawling akan dilakukan pembersihan dari data yang terduplikasi (redundant) serta menghilangkan noise pada atribut tweet yang merupakan atribut utama. Noise tersebut berupa angka, tanda baca, tautan, emoji, emoticon, hashtag dan mention, serta simbol - simbol yang tidak relevan. 
2. Stopwords filtering: Stopword merupakan daftar kata seperti kata depan, kata sambung, kata ganti, kata preposisi dan lain sebagainya yang tidak berpotensi dijadikan indeks dokumen karena kemunculannya tidak unik untuk sebuah dokumen tertentu [13]. Untuk itu kata-kata yang termasuk dalam daftar stopword perlu dihilangkan

3. Slang words replacing: Tahap ini bertujuan untuk mengganti kata - kata yang berbentuk slang dengan kata - kata yang lebih bersifat baku pada atribut tweet. Kata - kata slang seperti 'muaarah' diganti menjadi 'marah', 'brh' diganti menjadi 'buruh' dan sebagainya.

4. Stemming: Tahap ini bertujuan untuk mengubah kata - kata berimbuhan menjadi kata dasarnya seperti kata "berdemo" diganti menjadi "demo", kata "menolak" menjadi "tolak" dan lainnya.

5. Tokenizing: Tahap ini bertujuan untuk menguraikan paragraph atau kalimat menjadi elemen pembentuknya sehingga memudahkan dalam melakukan pemodelannya.

\section{Metode Analisis \\ Wordclouds}

Untuk memvisualisasikan beberapa kata yang sering muncul pada set data tweets, digunakan wordclouds. Frekuensi dari kata pada tweets ditunjukkan melalui ukuran kata pada output wordcloud. Semakin sering kata tersebut muncul dalam tweets, semakin besar ukuran kata, dan sebaliknya. Selain wordclouds, digunakan grafik batang dengan package ggplot 2 dan dplyr untuk melihat frekuensi kata yang sering muncul. Kemudian, dilakukan visualisasi sentiment polarity untuk melihat sentiment positif atau negative dengan package stringr dan plyr. Dan dilanjutkan dengan visualisasi sentiment emosi untuk melihat sentiment anger, joy, fear, sadness, dan surprise dengan package tidytext.

\section{Model naïve bayes}

1. Data dibagi menjadi dua bagian yaitu $80 \%$ training dan $20 \%$ testing.

2. Pada bagian data training dilakukan pelabelan kelas sentiment pada setiap tweet. Pelabelan kelas ini dilakukan dengan menggunakan kamus opinion lexicon. Apabila tweet mengandung lebih banyak jumlah kata yang bersifat positif dibanding negatif maka akan dilabelkan pada kelas sentiment positif dan sebaliknya. Ketika jumlah kata positif dan jumlah kata negatif sama akan diklasifikasikan kedalam sentiment netral.

3. Membangun model naïve bayes dengan package caret dan e1071.

4. Melakukan prediksi data testing dengan model yang telah dibentuk serta penghitungan akurasi.

\section{Model Asosiasi Kata}

Pemodelan ini bertujuan untuk memetakan kesamaan dan kecocokan satu kata dengan lainnya. Dengan menggunakan dataset sebelumnya dibangun model asosiasi kata dengan bantuan package $h 2 o$.

\section{PEMBAHASAN}

\section{Profile data}

Penelitian ini menggunakan data hasil proses scrapping pada Twitter dengan bantuan software Python. Pada proses scraping dihasilkan data sebanyak 89247 cuitan. Setelah dilakukan sampling sebanyak $10 \%$, data yang diperoleh ini perlu dilakukan preprocessing terlebih dahulu untuk menyeleksi data yang akan di digunakan. Langkah awal yang dilakukan yaitu proses preprocessing untuk menghindari kecacatan data saat proses analisis. Banyaknya data yang berhasil disaring setelah preprocessing yaitu sebanyak 8820 cuitan.

\section{Visualisasi Data}

Pada penelitian ini dilakukan visualisasi data yang bertujuan untuk mengetahui informasi tentang topik atau bahasan yang sering diulas oleh pengguna Twitter mengenai isu pengesahan RUU Omnibus Law atau RUU Cipta Kerja.

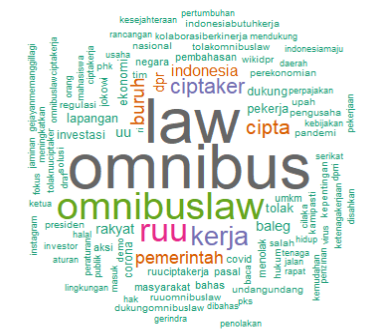

Gambar 4.1 Wordcloud ulasan Twitter 
Berdasarkan gambar wordcloud diatas, dapat dilihat bahwa kata "omnibus", "law", dan "omnibuslaw" merupakan kata yang paling mendominasi jika dibandingkan dengan katakata yang lain. Hal ini dikarenakan dalam cuitan yang membahas RUU Omnibus Law Cipta Kerja, banyak yang menggunakan kata-kata tersebut. Hasil wordcloud ini merupakan bentuk deskripsi yang masih umum. Untuk keterangan yang lebih rinci dapat dilihat pada tabel berikut.

Tabel 4.1 Jumlah Kata yang Paling Sering Muncul

\begin{tabular}{|c|c|c|}
\hline No. & Kata & Frekuensi \\
\hline 1. & omnibus & 5890 \\
\hline 2. & law & 5871 \\
\hline 3. & omnibuslaw & 3320 \\
\hline 4. & ruu & 2749 \\
\hline 5. & kerja & 1993 \\
\hline 6. & ciptaker & 1483 \\
\hline 7. & cipta & 1383 \\
\hline 8. & buruh & 1128 \\
\hline 9. & pemerintah & 1037 \\
\hline 10. & indonesia & 863 \\
\hline
\end{tabular}

Tabel 4.1 diatas menunjukkan jumlah kata yang paling sering muncul dalam 8820 cuitan. Hasil yang didapatkan sejalan dengan wordcloud dimana kata "omnibus", "law", dan "omnibuslaw" merupakan kata yang paling mendominasi. Kata "omnibus" muncul sebanyak 5890 kali, diikuti oleh "law" dengan rincian kemunculan sebanyak 5871 kali dan "omnibuslaw" dengan rincian kemunculan sebanyak 3320 kali. Selain itu, frekuensi katakata yang sering muncul adalah ciptaker, kerja, cipta, buruh yang menandakan bahwa cuitan twitter mengenai Omnibus Law sebagian besar membahas tentang masalah ketenagakerjaan. Hal tersebut sesuai dengan yang terjadi saat ini, bahwa banyak kaum buruh/pekerja yang merasa keberatan terhadap poin-poin dalam RUU Omnibus Law dan melakukan unjuk rasa dalam rangka penolakan terhadap Omnibus Law tersebut. Berikut Visualisasi dari tabel 4.1 dapat dilihat pada gambar 4.2

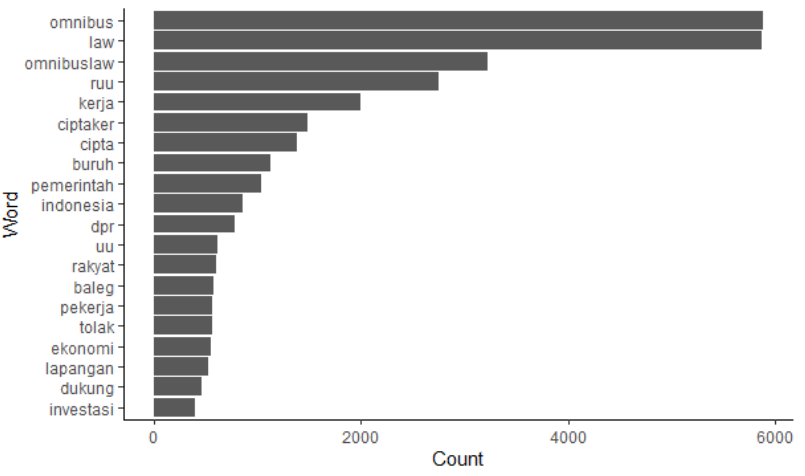

Gambar 4.2 Kata-Kata yang Muncul dengan Jumlah Terbanyak

\section{Pelabelan kelas sentiment}

Setelah melalui proses preprocessing, selanjutnya dilakukan pelabelan kelas sentiment berdasarkan respon pengguna Twitter terhadap RUU Omnibus Law Cipta Kerja. Pelabelan polaritas dibagi menjadi tiga kelas yaitu positif, negatif, dan netral. Namun, pada penelitian ini hanya menggunakan sentiment positif dan negatif saja. Hal ini dikarenakan sentiment netral kurang memberikan masukan kepada pemerintah terhadap isu pengesahan RUU ini. Setelah menghapus tweet dengan sentiment netral yang berjumlah 2975 cuitan, maka sisa data yang akan dianalisis yaitu berjumlah 5.845 cuitan dengan rincian pada Tabel 4.2.

Tabel 4.2 Hasil Pelabelan Sentimen

Berdasarkan Polaritas

\begin{tabular}{|c|c|c|}
\hline Sentimen & Frekuensi & Proporsi \\
\hline Positif & 2699 & $54 \%$ \\
\hline Negatif & 3146 & $46 \%$ \\
\hline
\end{tabular}

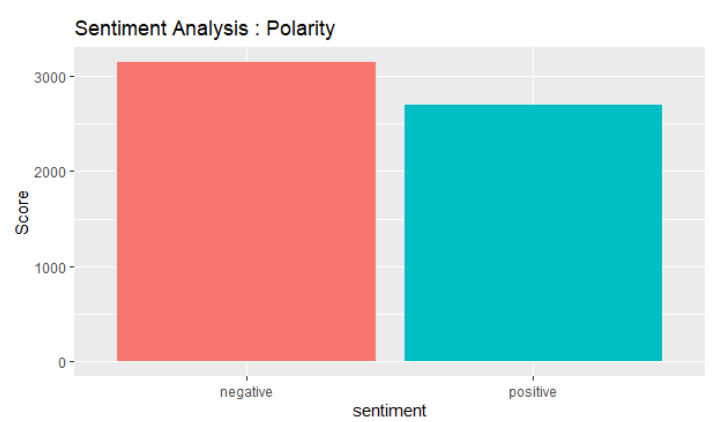

Gambar 4.3 Perbandingan Jumlah Sentimen Positif Negatif

Berdasarkan diagram batang di atas, dapat disimpulkan bahwa cuitan pengguna twitter mengenai RUU Omnibus Law Cipta Kerja 
periode 5 Januari sampai 30 Agustus tahun 2020 lebih banyak mengandung sentimen negatif. Frekuensi sentimen negatif yang berjumlah 3146, lebih besar dibandingkan sentiment positif yang berjumlah 2699. Sebanyak 54\% cuitan mengandung sentimen negatif terkait RUU Omnibus Law Cipta Kerja dimana hal itu berarti, mayoritas pengguna twitter yang membagikan cuitan mengenai RUU Omnibus Law Cipta Kerja cenderung menanggapi secara negatif atau menunjukkan ketidaksetujuan ataupun penolakan terhadap RUU ini. Sebanyak 46\% cuitan mengandung sentimen positif terkait RUU Omnibus Law Cipta Kerja yang berarti menunjukkan dukungan terhadap RUU Omnibus Law Cipta Kerja ini.

Selain diklasifikasikan berdasarkan polaritasnya, respon pengguna twitter dapat diklasifikasikan berdasarkan respon emosinya yang terdiri dari 5 kategori yakni anger (marah), fear (takut), joy (gembira), sadness (sedih), dan surprise (terkejut).

Tabel 4.3 Hasil Pelabelan Sentimen Berdasarkan Emosional

\begin{tabular}{|c|c|c|}
\hline Sentimen & Frekuensi & Proporsi \\
\hline Anger & 2359 & $17.5 \%$ \\
\hline Fear & 4020 & $30 \%$ \\
\hline Joy & 2613 & $19.3 \%$ \\
\hline Sadness & 2693 & $20 \%$ \\
\hline Surprise & 1792 & $13.3 \%$ \\
\hline
\end{tabular}

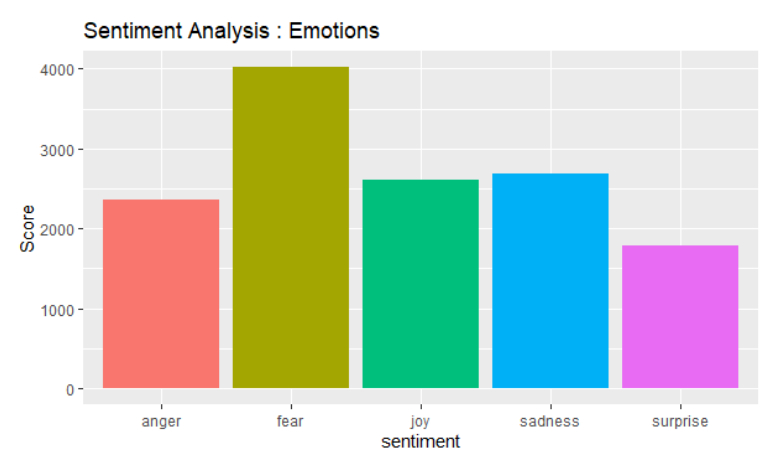

Gambar 4.4 Perbandingan Jumlah Sentimen Emosional

Berdasarkan diagram batang di atas, dapat disimpulkan cuitan pengguna Twitter mengenai RUU Omnibus Law Cipta Kerja periode 5
Januari sampai 30 Agustus tahun 2020 lebih banyak mengandung respon emosi fear dengan frekuensi kata berjumlah 4020 atau 30\% dari keseluruhan tweet. Jauh lebih besar dibandingkan respon emosi sadness (20\%), joy $(19,3 \%)$, anger (17,5\%), dan surprise (13,3\%). Hal ini menunjukkan mayoritas pengguna twitter merasa takut terhadap rencana pengesahan Undang-Undang Omnibus Law Cipta Kerja. Di sisi lain, sebanyak 20 persen pengguna twitter merasa sedih dengan rencana pengesahan Undang-Undang Omnibus Law Cipta Kerja. Meskipun begitu, masih terdapat 19,3 persen pengguna twitter merasa senang terhadap rencana pengesahan Undang-Undang Omnibus Law Cipta Kerja.

\section{Pemodelan Menggunakan Naïve Bayes Classifier}

Langkah pertama dalam mengklasifikasikan data tweet adalah melatih model menggunakan data training. Model yang telah dilatih dengan data training kemudian digunakan untuk mengklasifikasikan data testing ke dalam dua kelas sentimen, positif dan negatif. Klasifikasi dengan metode Naïve Bayes Classifier menghasilkan probabilitas yang digunakan untuk menentukan apakah tweet masuk ke dalam kategori sentimen positif atau negatif. Langkah selanjutnya adalah mengukur ketepatan klasifikasi pada data testing. Pengukuran ketepatan klasifikasi dilakukan dengan membentuk confusion matrix berdasarkan hasil prediksi. Berikut merupakan confusion matrix kategori aktual dan prediksi pada data testing.

Tabel 4.5 Confussion Matrix Data Testing

\begin{tabular}{|c|c|c|}
\hline \multirow{2}{*}{ Sentimen } & \multicolumn{2}{|c|}{ Frekuensi } \\
\cline { 2 - 3 } & Positif & Negatif \\
\hline Positif & 497 & 59 \\
\hline Negatif & 70 & 374 \\
\hline
\end{tabular}

Setelah terbentuk confusion matrix seperti pada Tabel 4.5, langkah selanjutnya adalah melakukan perhitungan ketepatan klasifikasi.

Tabel 4.6 Tabel ketepatan klasifikasi

\begin{tabular}{|l|l|}
\hline Akurasi & $\mathbf{0 , 8 7 1}$ \\
\hline Sensitivity & $\mathbf{0 , 8 7 7}$ \\
\hline
\end{tabular}




\begin{tabular}{|l|l|}
\hline Specificity & $\mathbf{0 , 8 6 4}$ \\
\hline Precision & $\mathbf{0 , 8 9 4}$ \\
\hline Recall & $\mathbf{0 , 8 7 7}$ \\
\hline F1-Score & $\mathbf{0 , 8 8 5}$ \\
\hline
\end{tabular}

Berdasarkan tabel 4.6 tersebut dapat diketahui bahwa klasifikasi pemodelan menggunakan Naïve Bayes Classifier menghasilkan akurasi sebesar 87,1 persen. Artinya, dari 100 tweets, 87 tweets dikategorikan benar berdasarkan model yang dibentuk. Sehingga model dapat dikatakan cukup baik untuk mengklasifikasikan respon pengguna twitter terhadap rencana pengesahan Undang-Undang Omnibus Law Cipta Kerja.

\section{Asosiasi Kata}

Berdasarkan kata-kata yang paling sering muncul dalam cuitan tentang RUU Omnibus Law Cipta Kerja, akan dilihat pula hubungan suatu kata dengan kata lainnya. Peluang kata-kata yang berasosiasi dengan kata yang paling sering muncul dapat dilihat pada tabel-tabel di bawah ini.

Tabel 4.7. Peluang saat Kata "investasi" Muncul

\begin{tabular}{|c|c|}
\hline Kata & Peluang \\
\hline meningkatkan & 0,73 \\
\hline regulasi & 0,63 \\
\hline umkm & 0,61 \\
\hline usaha & 0,59 \\
\hline pertumbuhan & 0,54 \\
\hline perzininan & 0,53 \\
\hline ekonomi & 0,52 \\
\hline nasional & 0,51 \\
\hline investor & 0,51 \\
\hline indonesia & 0,48 \\
\hline
\end{tabular}

Tabel 4.8 Peluang saat Kata "cipta" Muncul

\begin{tabular}{|c|c|}
\hline Kata & Peluang \\
\hline tenaga & 0,53 \\
\hline lapangan & 0,50 \\
\hline ruu & 0,46 \\
\hline umkm & 0,46 \\
\hline indonesiabutuhkerja & 0,45 \\
\hline pekerja & 0,45 \\
\hline
\end{tabular}

\begin{tabular}{|c|c|}
\hline pekerjaan & 0,44 \\
\hline pasal & 0,42 \\
\hline omnibus & 0,41 \\
\hline ketenagakerjaan & 0,40 \\
\hline
\end{tabular}

Tabel 4.9 Peluang saat Kata "buruh" Muncul

\begin{tabular}{|c|c|}
\hline Kata & Peluang \\
\hline Pekerja & 0,63 \\
\hline Demo & 0,60 \\
\hline pengusaha & 0,56 \\
\hline penolakan & 0,52 \\
\hline menolak & 0,51 \\
\hline upah & 0,50 \\
\hline serikat & 0,50 \\
\hline tolakomnibuslaw & 0,48 \\
\hline phk & 0,46 \\
\hline aksi & 0,46 \\
\hline
\end{tabular}

Pada tabel diatas, diperoleh beberapa asosiasi kata yang berhubungan dengan kata "investasi". Dapat dilihat bahwa kata "investasi" memiliki asosiasi dengan kata "meningkatkan" dan "pertumbuhan" yang mana tujuan dari RUU Omnibus Law Cipta kerja ini bertujuan untuk mempermudah izin untuk berinvestasi dalam rangka penyediaan lapangan pekerjaan serta meningkatkan pertumbuhan ekonomi Indonesia. Sedangkan untuk kata "cipta" sangat erat kaitannya dengan aspek ketenagakerjaan. Hal ini dapat kita lihat dari asosiasi terhadap kata kata "tenaga", "lapangan", "umkm", "indonesiabutuhkerja”, "pekerja”, "pekerjaan", dan "ketenagakerjaan". Hal ini dikarenakan tujuan lain dari RUU Omnibus Law Cipta Kerja yakni penyediaan lapangan kerja sebanyakbanyaknya. Sedangkan untuk kata "buruh" memiliki sentimen negatif terhadap isu ini. Hal ini dikarenakan kata "buruh" memiliki asosiasi terhadap kata "demo", "penolakan", "menolak", "tolakomnibuslaw", dan beberapa kata lainnya yang menunjukkan ketidaksetujuan terhadap adanya RUU Omnibus Law Cipta Kerja. 


\section{KESIMPULAN}

Berdasarkan hasil pengujian yang telah dilakukan, ada beberapa kesimpulan yang diperoleh. Kesimpulan tersebut antara lain:

a. Dari hasil pengolahan didapatkan 10 kata yang paling sering muncul seperti omnibus, law, omnibuslaw, ruu, kerja, ciptaker, cipta, buruh, pemerintah, Indonesia.

b. Respon masyarakat terhadap rencana pengesahan Undang-Undang Omnibus Law Cipta Kerja berdasarkan analisis sentimen yang dilakukan menunjukkan hasil yang negatif. Hal ini menunjukkan bahwa masyarakat tidak setuju dengan rencana pengesahan undang-undang tersebut.

c. Berdasarkan analisis asosiasi kata, kata investasi memiliki keterkaitan yang erat dengan pertumbuhan ekonomi serta kemudahan regulasi. Sedangkan kata cipta memiliki keterkaitan erat dengan penciptaan lapangan pekerjaan. Dan kata buruh memiiki keterkaitan erat dengan penolakan.

\section{DAFTAR PUSTAKA}

\section{Buku}

[1] Han, Jiawei., \& Kamber, Micheline. (2006), Data Mining: Concept and Techniques Second Edition, Morgan Kaufmann Publishers.

[2] Kusrini., Luthfi, Emha Taufik. (2009). Algoritma Data Mining. Yogyakarta: Penerbit Andi.

[3] Pramana, Setia., Yuniarto, Budi., Mariyah, Siti., Santoso, Ibnu., \& Nooraeni, Rani. (2019). Data Mining dengan R (Konsep serta Implementasi). Bogor: In Media.

\section{Jurnal}

[4] Darmawan, A. (2020). Politik Hukum Omnibus Law dalam Konteks Pembangunan Ekonomi Indonesia. Indonesian Journal of Law and Policy Studies, 1(1): 13-24.

[5] Fattah, Zainal., \& Fatanti, Megasari Noer. (2019). Mempolitisasi Ruang Virtual: Posisi Warga-Net dalam Praktik Demokrasi Digital di Indonesia. Jurnal Ilmiah Manajemen Publik dan Kebijakan Sosial, 3 (1).
[6] Lumbantoruan, H. D. (2017). Pembentukan Regulasi Badan Usaha dengan Model Omnibus Law. to-ra, 3(1): 463-472.

[7] Meilani, H. (2019). Hambatan dalam Meningkakan Investasi Asing di Indonesia dan Solusinya. Info Singkat Pusat Penelitian Badan Keahlian DPR RI, 9 (19).

[8] Sumadiasa, I Ketut. (2016). Analisis Pengaruh Pembangunan Infrastruktur Jalan, Listrik dan PMA terhadap Pertumbuhan PDRB Provinsi Bali tahun 1993- 2014. EJurnal EP Unud. Ed. 5, (7).

[9] Liu, B. (2012). Sentiment analysis and opinion mining. Synthesis lectures on human language technologies, 5(1), 1-167.

[10] Domingos, P., \& Pazzani, M. (1997). On the optimality of the simple Bayesian classifier under zero-one loss. Machine learning, 29(23), 103-130.

[11] Bimananda, W., Riski, I., Dwi, K., Nooraeni, R., Siahaan, T., \& Dhea, Y. (2019). Analisis Text Mining dari Cuitan Twitter Mengenai Infrastruktur di Indonesia dengan Metode Klasifikasi Naïve Bayes. EIGEN MATHEMATICS JOURNAL, I(2), 92-101.

[12] Han, J., Kamber, M., \& Pei, J. (2011). Data mining concepts and techniques third edition. The Morgan Kaufmann Series in Data Management Systems, 83-124.

[13] Rahutomo, F., \& Ririd, Ariadi RTH. (2018). Evaliasi Daftar Stopword Indonesia. Jurnal Teknologi Informasi dan Ilmu Komputer, 6(1), 41-48.

\section{Prosiding}

[14] Tan, A. H. (1999, April). Text mining: The state of the art and the challenges. In Proceedings of the PAKDD 1999 Workshop on Knowledge Discovery from Advanced Databases (Vol. 8, pp. 65-70). sn.

[15] Java, A., Song, X., Finin, T., \& Tseng, B. (2007, August). Why we twitter: understanding microblogging usage and communities. In Proceedings of the 9th WebKDD and 1st SNA-KDD 2007 workshop on Web mining and social network analysis (pp. 56-65).

[16] Huang, J., Lu, J., \& Ling, C. X. (2003, November). Comparing naive Bayes, decision trees, and SVM with AUC and 
accuracy. In Third IEEE International Conference on Data Mining (pp. 553-556). IEEE.

[17] Ristoski, P., Faralli, S., Ponzetto, S. P., \& Paulheim, H. (2017, August). Large-scale taxonomy induction using entity and word embeddings. In Proceedings of the International Conference on Web Intelligence (pp. 81-87).

\section{Informasi dari Internet}

[18] Wartaekonomi.co.id (2020, 06 Februari)"16 Paket Kebijakan Ekonomi Jokowi Gagal”. Diakses pada 15 September 2020, dari https://hot.liputan6.com/read/3924215/5cara-menulis-daftar-pustaka-dari-internetwajib-tahu-agar-tidak-salah.

[19] Kementerian Koordinator Bidang Perekonomian R.I, "Omnibus Law Cipta Lapangan Kerja" (Bahan sosialisasi RUU Cipta Lapangan Kerja, Jakarta, 17 Januari 2020). 